\title{
Relationship of Lymphocyte to Monocyte Ratio at Diagnosis with Prognosis in Patients with Diffuse Large B-cell Lymphoma: A Retrospective Study
}

\author{
Yaygın Büyük B Hücreli Lenfomalı Hastalarda Lenfosit Monosit Oranının Prognozla Ilișkisi: \\ Retrospektif Çalışma
}

\author{
(D) Ali ESER \\ Bezmialem Vakıf University Faculty of Medicine, Department of Internal Disease, Division of Hematology, istanbul, Turkey
}

\begin{abstract}
Aim: Although there is a complete response and increase in survival rates with rituximab in diffuse large-B-cell lymphoma (DLBCL), approximately $30 \%$ of the patients face with relapse or refractory disease. International prognostic index (IPI) is the most widely used method used for identifying relapse and refractory disease. Recently, the lymphocyte monocyte ratio (LMR) that can be used in place of or in combination with IPI has been proposed as an effective prognostic factor to predict clinical survival in DLBCL patients.

Materials and Methods: Two hundred twenty three patients diagnosed with DLBCL at our center between 2012 and 2020 were included in the study. The age, gender, absolute lymphocyte count (ALC), absolute monocyte count (AMC), and follow-up time were recorded from the files of the patients. Patients were divided into two groups as: exitus group and alive group. LMR was calculated.

Results: The median age at diagnosis was 58 years. The median ALC was $1.5 \times 10^{3} / \mathrm{uL}$, the median AMC was $0.6 \times 10^{3} / \mathrm{uL}$, and the median $\mathrm{LMR}$ was 2.6 . The median follow-up time was 53 months. Five-year overall survival and progression-free survival were $78 \%$ and $69 \%$, respectively. The age was significantly higher in the exitus group than in the alive group $(p<0.05)$. ALC, before and after treatment, was significantly higher in the exitus group than in the alive group ( $<<0.05)$. Pre-treatment AMC did not show a significant difference $(p>0.05)$. Pre-treatment LMR level did not show a significance difference in the exitus and alive groups ( $p>0.05)$.
\end{abstract}

Conclusion: LMR alone has low prognostic determinacy. Therefore, it should be evaluated with other prognostic determinants.

Keywords: Diffuse large B-cell lymphoma, absolute lymphocyte count, absolute monocyte count, lymphocyte-to-monocyte ratio

\section{ÖZ}

Amaç: Yaygın büyük B hücreli lenfomada (YBBHL) rituksimab ile birlikte tam yanıt ve sağkalım oranlarının artmasına rağmen hastaların yaklaşık \%30'u nüks veya dirençli hastalık ile karşı karşıyadır. Nüks ve dirençli hastalığın belirlenebilmesi için uluslararası prognostik indeks (UPi) en yaygın kullanılan metottur. Son zamanlarda UPi yerine veya birlikte kullanılabilecek lenfosit monosit oranı (LMO) YBBHL hastalarında klinik sağkalımı tahmin etmek için etkili bir prognostik faktör olarak önerilmiştir.

Gereç ve Yöntem: 2012-2020 yılları arasında merkezimizde YBBHL tanısı konulan 223 hasta çalışmaya dahil edildi. Hastaların dosyalarından yaşı, cinsiyeti, mutlak lenfosit sayısı (MLS), mutlak monosit sayısı (MMS), takip süresi kaydedildi. Hastalar ölüm ve yaşam grubu olarak ikiye ayrıldı. MLS MMS'ye bölünerek LMO hesaplandı.

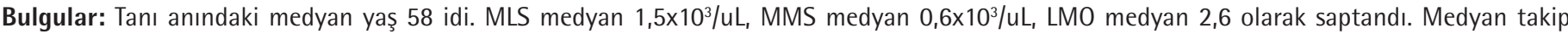
süresi 53 ay oldu. Beş yıllık genel sağkalım ve ilerlemesiz sağkalım sırasıyla \%78 ve \%69 olarak gerçekleşti. Ölüm grubunda hastaların yaşı yaşam grubundan anlamlı olarak daha yüksekti $(p<0,05)$. Ölüm grubunda tedavi öncesi ve tedavi sonrası MLS yaşam grubundan anlamlı olarak daha yüksekti $(p<0,05)$. Ölüm ve yaşam grubunda tedavi öncesi MMS açısından anlamlı farklılık görülmedi $(p>0,05)$. Ölüm ve yaşam grubunda tedavi öncesi LMO değerinde anlamlı ( $p>0,05)$ farklılık görülmedi.

Address for Correspondence: Ali ESER MD, Bezmialem Vakıf University Faculty of Medicine, Department of Internal Disease, Division of Hematology, İstanbul, Turkey Phone: +90 5322464105 E-mail: dralieser@gmail.com ORCID ID: orcid.org/0000-0001-9423-928X

Received: 18.01.2021 Accepted: 27.02.2021 
Sonuç: LMO'nun tek başına prognostik belirleyiciliği düşüktür. Bu nedenle diğer prognostik belirteçlerle birlikte değerlendirilmelidir.

Anahtar Kelimeler: Yaygın büyük B-hücreli lenfoma, mutlak lenfosit sayısı, mutlak monosit sayısı, lenfosit monosit oranı

\section{Introduction}

Diffuse large $B$ cell lymphoma (DLBCL) is the most common type of aggressive non-Hodgkin Iymphoma ${ }^{1}$. The median survival is less than one year in untreated patients ${ }^{2}$. Rituximab plus cyclophosphamide, vincristine, and prednisolone (R-CHOP) are the standard treatment for DLBCL and have a complete response rate of $70-90 \% 0^{3,4}$. However, approximately $30 \%$ of the patients face with relapse and refractory disease ${ }^{5}$. Prognostic evaluation is required to estimate patients with a relapse potential and high risk of refractory disease in DLBCL. For this purpose, prognostic factors such as international prognostic index (IPI), post-treatment positron emission tomography/computed tomography (PET/CT) and early interim evaluation, gene expression profile, $\mathrm{Ki}-67$ proliferation index are used $^{6-9}$. On the other hand, most of these methods are expensive and difficult to interpret. Therefore, there is a need for new methods that are inexpensive and easily accessible and interpreted by everyone. Recently, several studies have shown that the ratio of absolute lymphocyte/monocyte count (LMR) at diagnosis, which is obtained from a complete blood count, can predict clinical outcome in $\operatorname{DLBCL}^{10,11}$.

In this study, we aimed to demonstrate the efficiency of LMR in determining relapse and refractory cases and its usability with or without other prognostic determinants.

\section{MATERIALS AND METHODS}

The data from 223 adult patients with DLBCL, who were initially treated with R-CHOP at our hospital between 2012 and 2020, were retrospectively analyzed. A total of 27 patients were diagnosed with recurrent or primary refractory DLBCL. As a salvage therapy rituximab-ifosfamide, carboplatin, etoposide (R-ICE), rituximab-cisplatin, cytarabine, dexamethasone (R-DHAP), rituximab-bendamustine (R-Benda) were used, and afterwards autologous stem cell transplantation was performed. Laboratory levels were evaluated before starting R-CHOP chemotherapy. Diagnostic examinations of the patients were performed in our center. Laboratory results from the external center were not taken into consideration. Absolute lymphocyte count (ALC) and absolute monocyte count (AMC) were obtained from the complete blood count. LMR was calculated by using the ratio of ALC to AMC.

Bezmialem Vakıf University Ethics Committee approval was obtained from the Non-interventional Clinical Research Ethics Committee, with the protocol number of 20/380 and date of 01.12.2020.

\section{Statistical Analysis}

Mean, standard deviation, median, minimum, maximum value, frequency and percentage were used for descriptive statistics. The distribution of variables was checked with the KolmogorovSmirnov test. The Mann-Whitney $U$ test was used for the comparison of quantitative data. The Wilcoxon test was used for the repeated measurement analysis. The chi-square test was used for the comparison of the qualitative data. Statistical Package for the Social Sciences 27.0 was used for statistical analyses. Values of $p<0.05$ were considered significant.

\section{RESULTS}

Two hundred twenty three patients diagnosed with DLBCL and treated with $\mathrm{R}-\mathrm{CHOP}$ protocol were analyzed retrospectively in our center. The demographic characteristics of the patients are summarized in Table 1 . The median age at diagnosis was 58 years (range: 17-89). The median ALC was 1.5 (range: 0.2-61.3) $x 10^{3} / \mu \mathrm{L}$, the median AMC was 0.6 (range: $0.1-8.9$ ) $\times 10^{3} / \mu \mathrm{L}$, and the median LMR was 2.6 (range: 0.3-64.1). The median followup duration was 53 (range: 5-105) months.

Five-year overall survival (OS) and progression-free survival (PFS) were 78\% and 69\%, respectively. The median age of the patients in the exitus group was significantly higher than in the alive group $(p<0.05)$ (Figure 1$)$.

The gender distribution in neither exitus nor alive group did not differ significantly ( $p>0.05$ ) (Table 2). Pre and post-treatment

\section{Table 1. Baseline patient characteristics}

\begin{tabular}{|c|c|c|c|c|c|}
\hline & Min-Max & Median & Mean \pm SD & n (\%) \\
\hline \multicolumn{2}{|l|}{ Age } & $17.0-89.0$ & 58.0 & $57.0 \pm 16.2$ & \\
\hline \multirow{2}{*}{ Gender } & Female & & & & $\begin{array}{l}114 \\
(51.1)\end{array}$ \\
\hline & Male & & & & $\begin{array}{l}109 \\
(48.9)\end{array}$ \\
\hline \multicolumn{2}{|l|}{$\mathrm{ALC}(\mu \mathrm{L})$} & $0.2-61.3$ & 1.5 & $2.02 \pm 4.30$ & \\
\hline \multicolumn{2}{|l|}{$\mathrm{AMC}(\mu \mathrm{L})$} & $0.1-8.9$ & 0.6 & $0.72 \pm 0.69$ & \\
\hline \multicolumn{2}{|l|}{ LMR } & $0.3-64.1$ & 2.6 & $3.23 \pm 4.58$ & \\
\hline \multirow[t]{2}{*}{ Mortality } & $(-)$ & & & & $\begin{array}{l}147 \\
(65.9)\end{array}$ \\
\hline & $(+)$ & & & & $76(34.1)$ \\
\hline $\begin{array}{l}\text { Follow- } \\
\text { up time } \\
\text { (month) }\end{array}$ & & 5-105 & 53.0 & $41.7 \pm 15.4$ & \\
\hline
\end{tabular}

ALC: Absolute lymphocyte count, AMC: Absolute monocyte count, LMR: Lymphocte/ monocyte ratio, SD: Standard deviation, Min-Max: Minimum-maximum 
ALC values were significantly higher in the exitus group than in the alive group $(p<0.05)$ (Figure 2$)$.

In the alive group, ALC decreased significantly $(p<0.05)$ after the treatment compared to pre-treatment results. In the exitus group, ALC decreased significantly $(p<0.05)$ after the treatment compared to pre-treatment. The decrease in ALC after the treatment in the exitus group was significantly higher than in

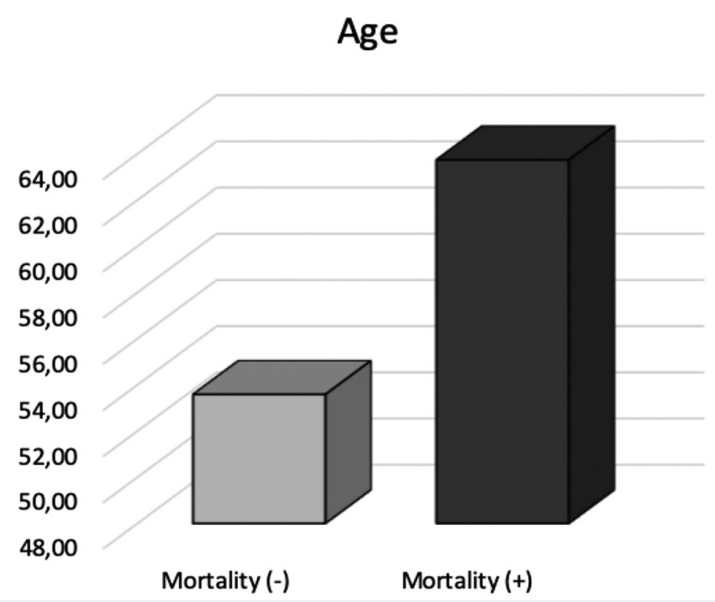

Figure 1. Age and mortality relationship in diffuse large-Bcell lymphoma patients the alive group $(p<0.05)$ (Table 2$)$. Pre-treatment AMC did not show a significant difference in both groups ( $p>0.05$ ). Posttreatment AMC in the exitus group was significantly higher than in the alive group $(p<0.05)$. Post-treatment $A M C$ in both groups did not show a significant change compared to pre-treatment status ( $p>0.05)$. The change in AMC after the treatment was not significantly ( $p>0.05)$ different between the exitus and alive groups (Table 2) (Figure 3).

Pre-treatment LMR level did not show a significant difference in the exitus and alive groups ( $p>0.05$ ). Post-treatment LMR in the exitus group was significantly higher than in the alive group $(p<0.05)$. Post-treatment LMR in the alive group showed a significant decrease compared to pre-treatment levels $(p<0.05)$. Post-treatment LMR in the exitus group did not show a significant difference compared to pre-treatment levels ( $p>0.05)$. Post-treatment LMR change was not significantly ( $p>0.05$ ) different between both groups (Table 2) (Figure 4).

\section{DISCUSSION}

The most critical point in the management of DLBCL is to identify patients with high risk of relapse and refractory disease with standard therapy. For that purpose, IPI is the most commonly used prognostic index to predict the results in naive and relapsed/refractory DLBCL. Many studies have shown the prognostic importance of IPI during relapsed/

Table 2. Comparison of ALC, AMC and LMR of mortality and non-mortality groups before and after treatment

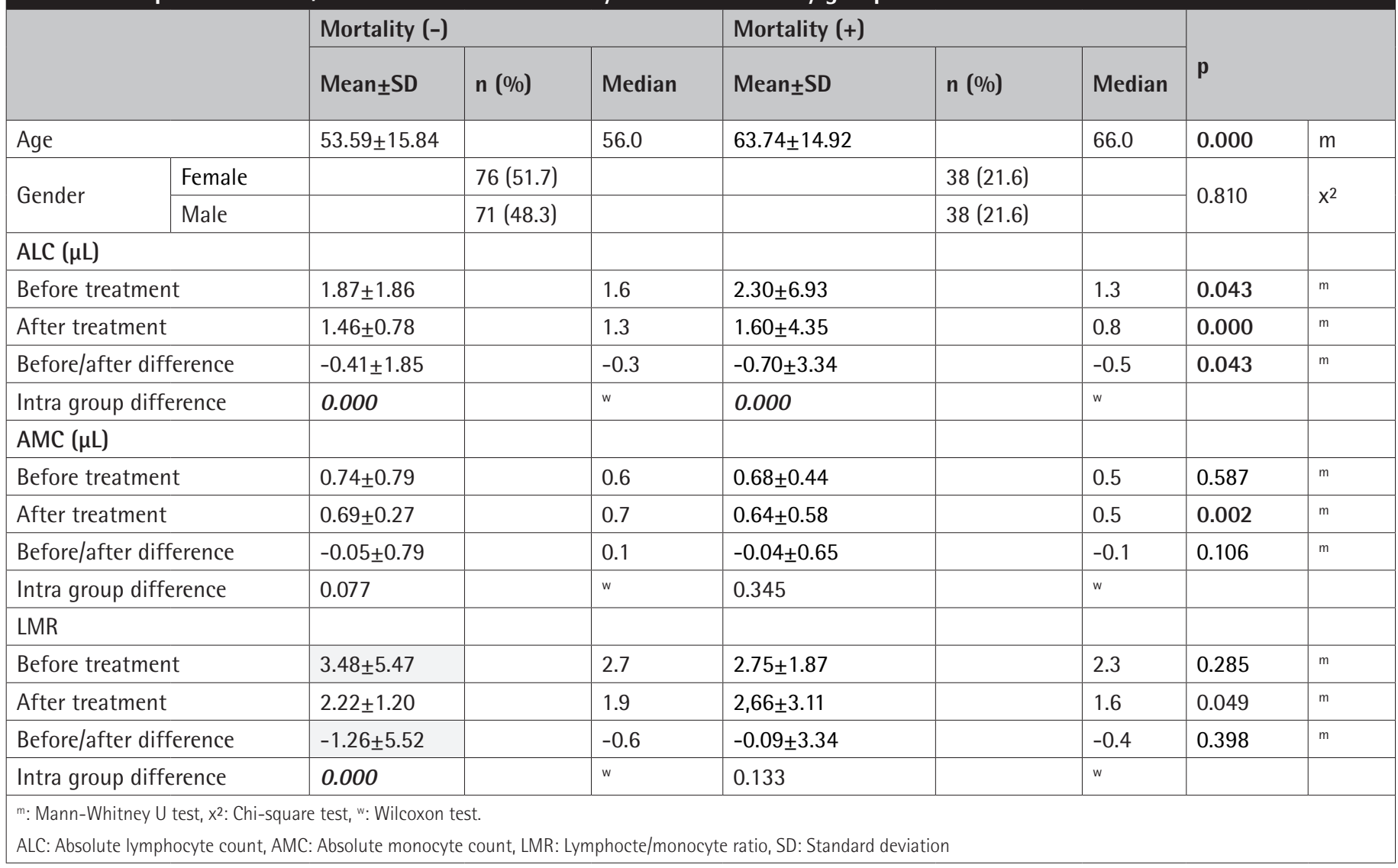




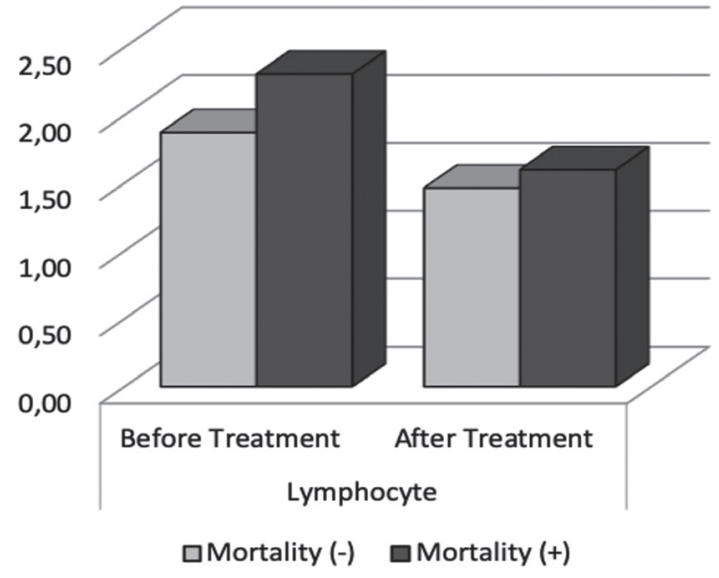

Figure 2. Absolute lymphocyte count and mortality relationship in diffuse large-B-cell lymphoma patients

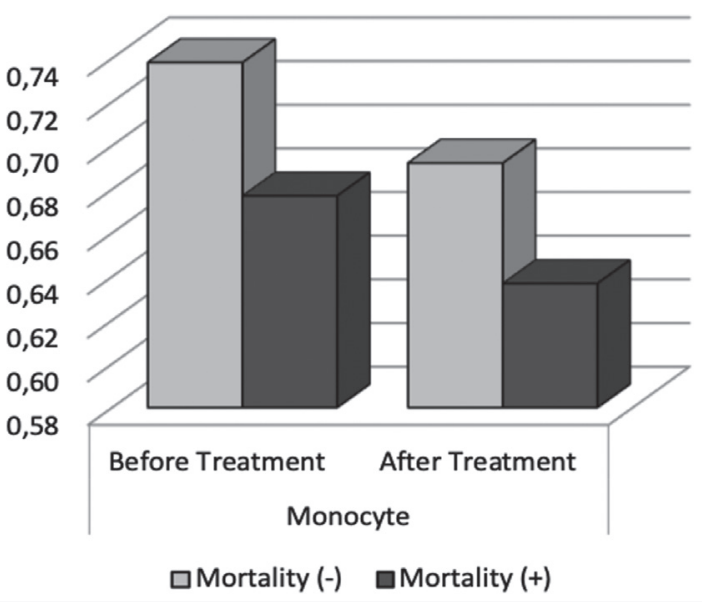

Figure 3. Absolute monocyte count and mortality relationship in diffuse large-B-cell lymphoma patients

refractory $\mathrm{DLBCL}^{12,13}$. In addition to this, it has been reported that IPI is less predictive and less beneficial during rituximab ${ }^{14}$. Therefore, some previous studies have shown that LMR could be a useful prognostic determinant for survival in DLBCL in order to demonstrate whether LMR improves predictive value in calculating the risk of patients with $\mathrm{DLBCL}^{15-18}$. ALC is a representative determinant of host immunity and AMC tumor microenvironment. Thus, LMR is a predictive biomarker for clinical outcomes in $\mathrm{DLBCL}^{19}$. However, one limitation point for LMR at initial diagnosis is that it cannot evaluate the host/ tumor interaction during treatment ${ }^{19}$.

Bento et al. ${ }^{20}$ established the cut-off levels as $1.1 \mu \mathrm{L}$ for ALC, $0.79 \mu \mathrm{L}$ for $\mathrm{AMC}$, and 2.25 for LMR in their study and emphasized that low LMR predicted both shorter PFS and also OS. In another study, Katoh et al. ${ }^{21}$ found it statistically significantly longer for 2 -year OS and PFS among patients with low $(<2.6)$ and high

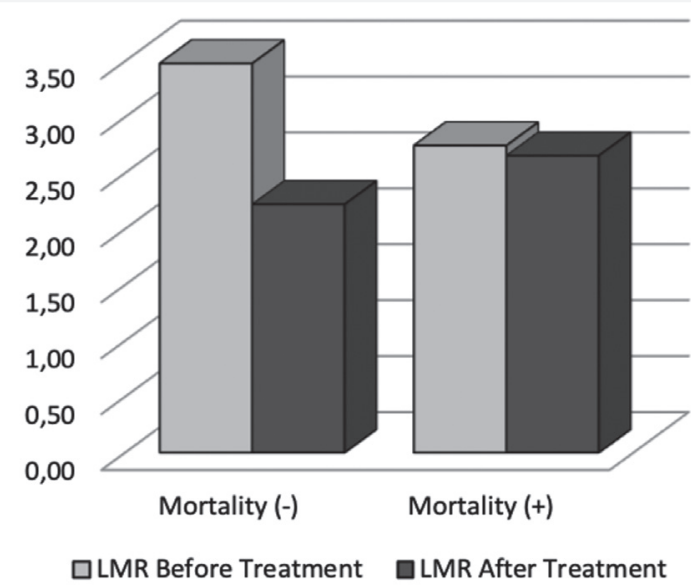

Figure 4. Lymphocte/monocyte ratio and mortality relationship in diffuse large-B-cell lymphoma patients

LMR: Lymphocte/monocyte ratio

LMR (>2.6) for patients with relapse/refractory DLBCL (79.4\% vs. $22.4 \% ; p<0.001$ and $68.9 \%$ vs $0 \% ; p<0.001)$. In addition, a low LMR was found in patients with primary resistance for recurrent diseases poor 2-year OS and PFS was predicted ${ }^{21}$. In our study, the median levels of ALC, AMC, and LMR were $1.6 \mu \mathrm{L}$, $0.6 \mu \mathrm{L}$, and 2.7, respectively. Contrary to previous studies ${ }^{15-17}$, pre-treatment and post-treatment ALC in the exitus group was significantly higher than in the alive group $(p<0.05)$. The decrease in ALC after the treatment in the exitus group was significantly higher than in the alive group $(p<0.05)$ (Table 2$)$. Pre-treatment AMC did not show a significant difference neither in both groups ( $p>0.05)$. Post-treatment AMC in the exitus group was significantly higher than in the alive group $(p<0.05)$ (Table 2). Pre-treatment LMR did not show a significant difference in both groups ( $p>0.05)$. Post-treatment LMR level in the exitus group was significantly higher than in the alive group $(p<0.05)$. Post-treatment LMR change did not differ significantly in both groups ( $p>0.05$ ) (Table 2).

However, there are a few limitations of using only LMR to determine patient prognosis. The survival outcomes of patients are not affected only by the immune system, but also by the specific characteristics of some tumors such as precise genetic mutations, pathology of tumors, and tumor size ${ }^{22,23}$. Chemotherapy or radiotherapy could affect the function of the immune cells $\mathrm{s}^{24-26}$. But the most importantly, count and functions of lymphocytes or monocytes could be regulated by tumor cells ${ }^{27}$. Therefore, LMR alone is probably not a perfect predictor of patients' clinical survival.

Similar to LMR, neutrophil-lymphocyte ratio (NLR) obtained from complete blood count can also be used to determine prognosis. Demircioglu et al. ${ }^{28}$ showed that NLR was associated with IPI and disease stage. 


\section{Study Limitations}

Our study has some limitations. The predictive value for OS and PFS, and the dynamic change of ratio during therapy, progression or relapse should also be confirmed in a larger population and at longer follow-up duration. Regular complete blood count should be performed to determine whether effective treatment will improve ALC and AMC.

\section{CONCLUSION}

In our study, contrary to previous studies, no significant effect of LMR on survival was detected. Therefore, LMR should be evaluated together with factors such as IPI, LDH, $\mathrm{Ki}-67$ proliferation index, and $\mathrm{PET} / \mathrm{CT}$. A larger patient group is needed to obtain more effective data.

\section{Acknowledgments}

Thank to Dr. Gunel Musayeva, who contributed to study by collecting the data.

\section{Ethics}

Ethics Committee Approval: Bezmialem Vakıf University Ethics Committee approval was obtained from the Noninterventional Clinical Research Ethics Committee, with the protocol number of 20/380 and date of 01.12.2020.

Informed Consent: Retrospective study.

Peer-review: Externally peer-reviewed.

Financial Disclosure: The author declared that this study received no financial support.

\section{References}

1. Flowers $C R$, Sinha $R$, Vose JM. Improving outcomes for patients with diffuse large B-cell lymphoma. CA Cancer J Clin. 2010;60:393-408.

2. Nastoupil $\amalg$, Rose $A C$, Flowers $C R$. Diffuse large B-cell lymphoma: current treatment approaches. Oncology (Williston Park). 2012;26:488-95.

3. Coiffier B, Lepage $E$, Briere J, Herbrecht R, Tilly $H$, Bouabdallah $R$, et al. $\mathrm{CHOP}$ chemotherapy plus rituximab compared with $\mathrm{CHOP}$ alone in elderly patients with diffuse large-B-cell lymphoma. N Engl J Med. 2002;346:23542.

4. Pfreundschuh $M$, Trümper $L$, Osterborg $A$, Pettengell $R$, Trneny $M$, Imrie $\mathrm{K}$, et al. CHOP-like chemotherapy plus rituximab versus $\mathrm{CHOP}$-like chemotherapy alone in young patients with good-prognosis diffuse large-B-cell lymphoma: a randomised controlled trial by the MabThera International Trial (MInT) Group. Lancet Oncol. 2006;7:379-91.

5. Sehn LH, Donaldson J, Chhanabhai M, Fitzgerald C, Gill K, Klasa R, et al. Introduction of combined $\mathrm{CHOP}$ plus rituximab therapy dramatically improved outcome of diffuse large B-cell lymphoma in British Columbia. J Clin Oncol. 2005;23:5027-33.

6. International Non-Hodgkin's Lymphoma Prognostic Factors Project. A predictive model for aggressive non-Hodgkin's lymphoma. N Engl J Med. 1993;329:987-94.

7. Mikhaeel NG. Interim fluorodeoxyglucose positron emission tomography for early response assessment in diffuse large B cell lymphoma: where are we now? Leuk Lymphoma. 2009;50:1931-6.
8. Rosenwald A, Wright G, Chan WC, Connors JM, Campo E, Fisher RI, et al. The use of molecular profiling to predict survival after chemotherapy for diffuse large-B-cell lymphoma. N Engl J Med. 2002;346:1937-47.

9. Broyde A, Boycov 0, Strenov Y, Okon E, Shpilberg O, Bairey O. Role and prognostic significance of the Ki-67 index in non-Hodgkin's lymphoma. Am J Hematol. 2009;84:338-43.

10. Markovic O, Popovic L, Marisavljevic D, Jovanovic D, Filipovic B, Stanisavljevic D, et al. Comparison of prognostic impact of absolute lymphocyte count, absolute monocyte count, absolute lymphocyte count/ absolute monocyte count prognostic score and ratio in patients with diffuse large B cell lymphoma. Eur J Intern Med. 2014;25:296-302.

11. Li YL, Gu KS, Pan YY, Jiao Y, Zhai ZM. Peripheral blood lymphocyte/ monocyte ratio at the time of first relapse predicts outcome for patients with relapsed or primary refractory diffuse large B-cell lymphoma. BMC Cancer. 2014;14:341.

12. Hamlin PA, Zelenetz AD, Kewalramani T, Oin J, Satagopan JM, Verbel D, et al. Age-adjusted International Prognostic Index predicts autologous stem cell transplantation outcome for patients with relapsed or primary refractory diffuse large B-cell lymphoma. Blood. 2003;102:1989-96.

13. Gisselbrecht C, Glass B, Mounier N, Singh Gill D, Linch DC, Trneny M, et al. Salvage regimens with autologous transplantation for relapsed large B-cell lymphoma in the rituximab era. J Clin Oncol. 2010;28:4184-90.

14. Ngo L, Hee SW, Lim LC, Tao M, Quek R, Yap SP, et al. Prognostic factors in patients with diffuse large $B$ cell lymphoma: Before and after the introduction of rituximab. Leuk Lymphoma. 2008;49:462-9.

15. Kim DH, Baek JH, Chae YS, Kim YK, Kim HJ, Park YH, et al. Absolute lymphocyte counts predicts response to chemotherapy and survival in diffuse large B-cell lymphoma. Leukemia. 2007;21:2227-30.

16. Cox MC, Nofroni I, Laverde G, Ferrari A, Amodeo R, Tatarelli C, et al. Absolute lymphocyte count is a prognostic factor in diffuse large B-cell lymphoma. Br J Haematol. 2008;141:265-8.

17. Feng J, Wang Z, Guo X, Chen Y, Cheng Y, Tang Y. Prognostic significance of absolute lymphocyte count at diagnosis of diffuse large B-cell lymphoma: a meta-analysis. Int J Hematol. 2012;95:143-8.

18. Tadmor T, Bari A, Sacchi S, Marcheselli L, Liardo EV, Avivi I, et al. Monocyte count at diagnosis is a prognostic parameter in diffuse large B-cell lymphoma: results from a large multicenter study involving 1191 patients in the pre- and post-rituximab era. Haematologica. 2014;99:125-30.

19. Porrata LF, Ristow KM, Habermann TM, Witzig TE, Colgan JP, Inwards DJ, et al. Peripheral blood absolute lymphocyte/monocyte ratio during rituximab, cyclophosphamide, doxorubicin, vincristine and prednisone treatment cycles predicts clinical outcomes in diffuse large B-cell lymphoma. Leuk Lymphoma. 2014;55:2728-38.

20. Bento L, Díaz-López A, Barranco G, Martín-Moreno AM, Baile M, Martín A et al. New prognosis score including absolute lymphocyte/monocyte ratio, red blood cell distribution width and beta- 2 microglobulin in patients with diffuse large B-cell lymphoma treated with R-CHOP: Spanish Lymphoma Group Experience (GELTAMO). Br J Haematol. 2020;188:888-97.

21. Katoh D, Ochi Y, Yabushita T, Ono Y, Hiramoto N, Yoshioka S, et al. Peripheral Blood Lymphocyte-to-Monocyte Ratio at Relapse Predicts Outcome for Patients With Relapsed or Refractory Diffuse Large B-cell Lymphoma in the Rituximab Era. Clin Lymphoma Myeloma Leuk. 2017;17:91-7.

22. Reddy A, Zhang J, Davis NS, Moffitt AB, Love CL, Waldrop $A$, et al. Genetic and Functional Drivers of Diffuse Large B Cell Lymphoma. Cell. 2017;171:481-94.

23. Leivonen SK, Taskinen M, Cervera A, Karjalainen-Lindsberg ML, Delabie J Holte $\mathrm{H}$, et al. Alternative splicing discriminates molecular subtypes and has prognostic impact in diffuse large B-cell lymphoma. Blood Cancer J. 2017;7:e596.

24. Zhou S, Xu L, Ma Y, Tang L, Zhang Y, Shi Y, et al. Peripheral blood lymphocyte to monocyte ratio recovery from low levels at diagnosis after completion of first line therapy predicts good clinical outcomes in patients with diffuse large B-cell lymphoma. Oncotarget. 2017;8:19556-65. 
25. Porrata LF, Ristow KM, Habermann TM, Macon WR, Witzig TE, Colgan JP, et al. Peripheral blood absolute lymphocyte/monocyte ratio recovery during ABVD treatment cycles predicts clinical outcomes in classical Hodgkin lymphoma. Blood Cancer J. 2013;3:e110.

26. Lin GN, Liu PP, Liu DY, Peng JW, Xiao JJ, Xia ZJ. Prognostic significance of the pre-chemotherapy lymphocyte-to-monocyte ratio in patients with previously untreated metastatic colorectal cancer receiving FOLFOX chemotherapy. Chin J Cancer. 2016;35:5.
27. Su S, Liu Q, Chen J, Chen J, Chen F, He C, et al. A positive feedback loop between mesenchymal-like cancer cells and macrophages is essential to breast cancer metastasis. Cancer Cell. 2014;25:605-20.

28. Demircioglu S, Dogan A, Ekinci O, Demir C. The Association of NLR and MPV with Treatment Responses, Disease Stages and International Prognostic Index Scores in DLBCL. East J Med. 2019;24:325-9. 